\title{
Numerical Study of Mixed Convection in a Cooled Room
}

\author{
Dedy Zulhidayat Noor ${ }^{1}$, Heru Mirmanto ${ }^{1}$, Eddy Widiyono ${ }^{1}$, and Liza Rusdiyana ${ }^{1}$
}

\begin{abstract}
The present work is carried out to study laminar mixed convection heat transfer inside a rectangular cooled room numerically. The chosen model is considered as a representation of a room facing the sun with a floor releasing heat resulted by electronic components or human activities. The Reynolds number and Richardson number are varied from 100 to 400 and 0 to 3, respectively, in order to cover laminar mixed convection phenomena. For the considered range of Re dan $\mathrm{Ri}$, the flow regimes fall into three modes i.e. a simple flow without circulation zone, the two circulation zones between the main stream and a single big circulation zones near the hot walls. The higher Nusselt numbers are found at the higher values of $\mathrm{Re}$, on the other hand, the forced convection leads to higher heat transfer rate than the free/natural convection.
\end{abstract}

Keywords— numerical method, mixed convection, cooled room, heat transfer.

Abstrak - Karya ini dilakukan untuk mempelajari laminar campuran perpindahan panas konveksi di dalam persegi panjang yang didinginkan ruang numerik. Model yang dipilih dianggap sebagai representasi dari kamar yang menghadap matahari dengan lantai melepaskan panas yang dihasilkan oleh komponen elektronik atau aktivitas manusia . Jumlah Reynolds dan nomor Richardson bervariasi 100-400 dan 0-3, masing-masing, dalam rangka untuk menutupi laminar fenomena konveksi campuran . Untuk kisaran dianggap Re Dan Ri , rezim aliran jatuh ke dalam tiga mode yaitu aliran sederhana tanpa zona sirkulasi , dua zona sirkulasi antara arus utama dan satu sirkulasi zona besar dekat dinding panas . Semakin tinggi angka Nusselt ditemukan di nilai yang lebih tinggi dari Re, di sisi lain , konveksi paksa menyebabkan laju perpindahan panas yang lebih tinggi daripada bebas / konveksi alami

Kata Kunci-metode numerik , campuran konveksi , ruang didinginkan , perpindahan panas

\section{INTRODUCTION}

$\mathrm{M}$ ixed convection is encountered in many engineering applications i.e. heat transfer devices, such as heat exchanger, nuclear power plant, electronic equipments, cooling and heating room. It is a combination of the forced convection induced by the blown fluid and the thermal buoyancy forces induced by the temperature difference between the surface and the free stream (free/natural convection). The interaction between forced and free convection plays an important role in controlling heat transfer rate and has been the subject of investigations for many years.

A large number of investigations in different applications of mixed convection have been performed by people. Among the applications of mixed convection in engineering field, air is the most common fluid to be used for cooling methods due to its simplicity and low cost operation.

Some works had carried out a numerical study of mixed convection in a cavity with a localized heat source [1], [2]. It was reported that flow patterns generally consist of recirculating cells due to buoyancy forces generated by the heat source. The other work had investigated mixed convection from simulated electronic component as heat sources at varying relative positions in a cavity. Placing the heat source on the right vertical wall was the most favorable in terms of cooling/heat removing [3].

A mixed convection in an air-cooled cavity had been studied as well [4]. The chosen configuration could represent a room facing the sun or an enclosure with

${ }^{1}$ Dedy Zulhidayat Noor, Heru Mirmanto, Eddy Widiyono, and Liza Rusdiyana are with Departement of Mechanical Engineering, Faculty of Industrial Technology, Institut Teknologi Sepuluh Nopember, Surabaya, 60111, Indonesia. Email: zulnoor@me.its.ac.id. electronic components. The dynamic and thermal fields were numerically determined for a large range of Reynolds and Richardson numbers and for different inlet-outlet locations. Two different placement configurations of the inlet and outlet openings on the side walls were investigated. In the first case the cold air was injected at the top of the hot wall and exited at the bottom of the cold wall, whereas in the second configuration the injection was at the lower edge of the hot wall and the exit was at the top of the cold wall. Improvement in cooling efficiency was found with the inlet placed at the bottom of the hot wall. The other researchers had extended the work done by [4] in which only two possible placement configurations of the inlet and outlet with the inlet always at the hot wall were investigated [5]. They investigated six configurations of the inlet and outlet, including those of [4] by considering the injection the cold air from both the cold and hot wall. They found that injection from the cold wall produce more effective cooling due to impinging effect from the incoming cold air jet.

A numerical study of opposing mixed convection in a vented enclosure had been performed using finite element method [6]. The geometry was a square vented cavity with one of the side wall heated uniformly and the other walls insulated. The inlet port was located on different locations of the insulated left wall whereas the outlet port was fixed on the top wedge of the heated right wall. The researchers studied the effects of Prandtl, Richardson and Reynolds numbers on the heat transfer characteristics of laminar mixed convection. It was found that with the increase of Reynolds and Richardson numbers the convective heat transfer became predominant over the conduction heat transfer and the rate of heat transfer from the heated wall significantly depended on the position of the inlet port whereas higher 
Nusselt number was observed at very large Prandtl number.

A HD mixed convection in a double-lid driven cavity with a heat-generating solid square block had been simulated [7]. Some relevant parameters such as block diameter, location of the block and Richardson number were varied in order to investigate flow field and heat transfer characteristic. The obtained results revealed that the flow and thermal field were strongly influenced by those parameters.

More recently, an investigation of mixed convection in a square cavity having adiabatic circular cylinder had been conducted [8]. The top and bottom walls of the cavity were heated temperature while the other sidewalls were kept adiabatic. The inlet port located on the left-top adiabatic vertical wall and the outlet port on the rightbottom vertical wall. A finite element method for steadystate incompressible mixed convection flow derived from the conservation of mass, momentum, and energy equations were used in order to determine to the fluid flow and heat transfer characteristics in the cavity as a function of Reynolds number $(R e)$, Prandtl number $(P r)$, Richardson number $(R i)$ and diameter of the cylinder (dr). The higher average Nusselt number was found for the higher values of Re and Pr. Increasing Ri made the concentrated thermal layer near the heated surface became thin and created a larger recirculation cell in the streamline while a larger cylinder diameter reduced buoyancy-induced circulation cell inside the cavity.

The present study is a modification of the work done by the previous researchers [4], [5] and [6]. The current geometry is considered as a rectangular cavity with a constant hot temperature, applied on the bottom and the left vertical walls while the right and top walls are cold and adiabatic surfaces, respectively. The chosen model can be considered as a representation of a room facing the sun with a floor releasing heat resulted by electronic components or human activities.

The inflow opening located on the top wall is fixed as shown in the Figure 1. Air with constant $\mathrm{Pr}=0.7$ is used as the working fluid. The boundary conditions of the current work are given as follows

$\begin{array}{ll}\text { - Inlet } & : u=0 ; v=-1 ; \theta=-0.5 \\ \text { - Outlet } & : u, v \text { and } \theta \text { are extrapolated from the }\end{array}$ two immediate upstream inside nodes along the grid line

$$
\begin{array}{ll}
\text { - Top wall } & : u=v=0 ; \frac{\partial \theta}{\partial x}=0 \\
\text { - Bottom wall } & : u=v=0 ; \theta=1 \\
\text { - Left wall } & : u=v=0 ; \theta=1 \\
\text { - Right wall } & : u=v=0 ; \theta=0
\end{array}
$$

The outflow opening of the cavity is arranged at the right-bottom wall. The size of the inlet port is the same size as the exit port which is equal to $w=0.1 \mathrm{~L}$. The primary focus of this paper is to investigate the influence of the range of Richardson number and Reynolds number on the hot surface heat transfer.

\section{METHOD}

The two-dimensional Navier-Stokes equations, continuity and energy equations in primitive variables for an unsteady incompressible laminar viscous flow with the Boussinesq assumption are denoted in dimensionless forms using the following dimensionless variables

$$
\begin{aligned}
& x=\frac{X}{H} \quad y=\frac{Y}{H} \quad u=\frac{U}{U_{0}} \quad v=\frac{V}{V_{0}} \quad \theta=\frac{T-T_{C}}{T_{H}-T_{C}} \\
& p=\frac{P}{\rho U_{0}^{2}} \quad \operatorname{Re}=\frac{V_{0} L}{v} \quad \operatorname{Pr}=\frac{v}{\alpha} \quad G r=\frac{g \beta\left(T-T_{C}\right) H^{3}}{v^{2}}
\end{aligned}
$$

Hence, the non-dimensional governing equations are continuity equation,

$\frac{\partial u}{\partial x}+\frac{\partial v}{\partial y}=0$

momentum equation,

$\frac{\partial u}{\partial t}+u \frac{\partial u}{\partial x}+v \frac{\partial u}{\partial y}=-\frac{\partial p}{\partial x}+\frac{1}{\operatorname{Re}} \nabla^{2} u$

$\frac{\partial v}{\partial t}+u \frac{\partial v}{\partial x}+v \frac{\partial v}{\partial y}=-\frac{\partial p}{\partial y}+\frac{1}{\operatorname{Re}} \nabla^{2} v+\frac{G r}{\operatorname{Re}^{2}} \theta$

energy equation,

$\frac{\partial \theta}{\partial t}+u \frac{\partial \theta}{\partial x}+v \frac{\partial \theta}{\partial y}=\frac{\nabla^{2} \theta}{\operatorname{Re} \operatorname{Pr}}$

Where $u, v, p$ and $\theta$ are the dimensionless variables of velocity components in the $x$ and the $y$-directions, pressure and temperature, respectively. $R e, G r$ and $P r$ are the Reynolds number, Grashof number and Prandtl number, respectively, while Richardson number is defined as $G r / R e^{2}$. The overall mean Nusselt number ( $\overline{N u}_{\text {overal }}$ ) is counted by including average Nusselt number on left $\left(\overline{N u}_{\text {left }}\right)$ and bottom ( $\left.\overline{N u}_{\text {bottom }}\right)$ walls as follows,

$\overline{N u}_{\text {left }}=\frac{1}{\mathrm{H}} \int_{0}^{\mathrm{H}} \frac{d \theta}{d x} d y$ and $\overline{N u}_{\text {bottom }}=\frac{1}{\mathrm{~L}} \int_{0}^{\mathrm{L}} \frac{d \theta}{d y} d x$.

Hence,

$$
\overline{N u}_{\text {overal }}=\frac{\int_{0}^{\mathrm{H}} \frac{d \theta}{d x} d y+\int_{0}^{\mathrm{L}} \frac{d \theta}{d y} d x}{\mathrm{H}+\mathrm{L}} .
$$

The diffusive terms of Eqs. (3) and (4) are discretized using the second-order central difference scheme while the convective terms are discretized using the quadratic upstream interpolation for convective kinetics (QUICK) scheme. The fourth-order Runge-Kutta method is used for the solution of the transient terms while the pressure terms are solved by using SOLA method by [9].

\section{RESULT AND DISCUSSION}

\section{A. Grid Independence Study}

We performed a grid independence test in order to check the sensitivity of grid size using in our simulation. The in-house numerical code using by [10] was modified for the present work. We picked the case of $R e=200$ and $R i=1$ to count the overall mean Nusselt number ( $\overline{N u}_{\text {overal }}$ ). Simulations with four non-uniform grid sizes have been carried out and presented in Table 1 . Furthermore, the $100 \times 100$ grid size was chosen and used for all simulation in the current study.

\section{B. The Flow And Thermal Fields}

For the considered $\mathrm{Re}$ and $\mathrm{Ri}$, the flow patterns fall into three modes as shown in Figure 2. The first mode is found at $\mathrm{Ri}=0$ (forced convection) and low $\mathrm{Re}=100$. Air simply flowing from inlet to outlet. When $\mathrm{Re}$ 
increases, due to a higher inertia force, air comes down along the left wall, attaches with the bottom wall and then goes out towards outlet port. Two circulation zones are observed entire the flow field. A big one is found between the top and the right walls while the small one is emerged at the corner between the left and the bottom walls. This flow patterns is categorized as the second mode. The circulating zone grows in size at higher Re value. For the case of mixed convection $(\mathrm{Ri}=1)$ in which buoyancy and inertia forces are equally dominant, the size of the circulation zone at the left-bottom corner is getting bigger and even surpassing the anticlockwise recirculatory cell at the top-right corner when $\mathrm{Ri}$ increases. When buoyancy effects are pronounced and natural/free convection dominates the flow field $(\mathrm{Ri}>1)$, the flow patterns changes into the third mode. Air flow is pushed up and it travels along the top and right walls before going out through outlet port. The hot left and bottom walls create the natural convection boundary layer and rises up the secondary flow around the central region but closer to the hot walls due to buoyancy.

The isotherm contours are plotted in Figure 3. The lowest isotherms are the main fluid streams resulted by the incoming cold air from the inlet which is directed to the exit. The entire thermal field is governed by the formation of the circulating vortex, its location and interaction with the main cold air stream.

Temperature is observed to be more uniform in the circulation zones. Its value is influenced by the location of circulation zones. For the case of forced convection, uniform low isotherms are found above the main stream, while the high isotherms are accordingly clustered close to the hot bottom wall, which manifestes the existence of high temperature gradient. On the other hand, when Ri increase and natural/free convenction governs the thermal field, high isotherms are observed between the two hot walls i.e. the left and bottom walls while the low isotherms are more concentrated near the adiabatic walls i.e the top and right walls. Both the low isotherms above the main stream and the high isotherms below the main stream for forced and natural/free convection, respectively, are formed more uniformly when $\mathrm{Re}$ increases. Uniform isotherms reveal a low temperature gradient and indicate a low energy transfer among fluid layers which are trapped inside circulation/vortex zones.

Plot of $\overline{N u}_{\text {overal }}$ for all cases are presented in Figure 4. Heat transfer, revealed by $\overline{N u}_{\text {overal }}$, is enhanced by increasing Re. It can be observed that $\overline{N u}_{\text {overal }}$ for the forced convection increases sharply and linearly for the higher values of $\mathrm{Re}$ while it increases gradually for mixed and natural/free convections. It is found that $\overline{N u}_{\text {overal }}$ decreases for higher $\mathrm{Ri}$ when buoyancy is strengthened at free convection dominated region.

\section{CONCLUSION}

A numerical study of mixed convection inside a cooled room has been performed. The Reynolds and Richardson numbers are varied from 100 to 400 and 0 to 1 , respectively. The flow field can be categorized into three flow regimes. The first mode is found at the case of forced convection with low Re. The fluid simply flowing from inlet to outlet. The second mode with two circulation zones between the main stream appears for higher Re while the third mode consist of single big circulation zone near the hot walls occurs when the natural/free convection dominated the flow field due to buoyancy. The entire thermal field is affected by the formation of the circulating vortex and its location which is governed by the values of Re and Ri. Furthermore, the highest overall Nusselt number is obtained by the highest Re while the forced convection tends to lead a higher heat transfer rate than the free/natural convection.

\section{ACKNOWLEDGMENTS}

Authors thank university for providing the computing facility and references in order to carry out the present work.

\section{REFERENCES}

[1] E. Papanicolaou and Y. Jaluria, "Mixed Convection from an Isolated Heat Source in a Rectangular Enclosure," Numerical Heat Transfer, Part A, vol. 18, no. 4, pp. 427-461, 1991.

[2] E. Papanicolaou and Y. Jaluria, "Mixed Convection from A Localized Heat Source in A Cavity with Conducting Walls: A Numerical Study," Numerical Heat Transfer, Part A, vol. 23, no. 4, pp. 463-484, 1993.

[3] E. Papanicolaou and Y. Jaluria, "Mixed Convection from Simulated Electronic Component as Heat Sources at Varying Relative Positions in A Cavity," ASME Journal of Heat Transfer, vol. 116, no. 4, pp. 960-970, 1994.

[4] A. Omri and S. B. Nasrallah, "Control Volume Finite Element Numerical Simulation of Mixed Convection in An Air-Cooled Cavity,," Numerical Heat Transfer, Part A, vol. 36, no. 6, pp. 615637, 1999.

[5] S. Singh and M. A. R. Sharif, "Mixed Convective Cooling of A Rectangular Cavity with Inlet and Exit Openings on Differentially Heated Side Wall," Numerical Heat Transfer, Part A, vol. 44, no. 3, pp. 233-253, 2003.

[6] M. M. Rahman, M. A. Alim, M. A. H. Mamun, M. K. Chowdhury and A. K. M. S. Islam, "Numerical Study of Opposing Mixed Convection in A Vented Enclosure," ARPN Journal of Engineering and Applied Sciences, vol. 2, no. 2, pp. 25-36, 2007.

[7] M. M. Billah, M. M. Rahman, R. Saidur and M. Hasanuzzaman, "Simulation of MHD Mixed Convection Heat Transfer Enhancement in A Double Lid-Driven Obstructed Enclosure," International Journal of Mechanical and Materials Engineering, vol. 6, no. 1, pp. 18-30, 2011.

[8] M. N. Uddin and M. A. Alim, "Numerical Analysis of Mixed Convection in A Square Cavity Having Adiabatic Circular Cylinder," International Journal of Theoretical \& Applied Sciences, vol. 5, no. 1, pp. 111-118, 2013.

[9] C. W. Hirt, B. D. Nichols and N. C. Romero, "SOLA - A Numerical Solution Algorithm for Transient Fluid Flow," Los Alamos Scientific Laboratory, USA, Los Alamos, 1975.

[10] D. Z. Noor, M. J. Chern and P. R. Kanna, "Flow and Heat Transfer in A Driven Square Cavity with Double-Sided Oscillating Lids in Anti-Phase," International Journal of Heat and Mass Transfer, vol. 52, no. 13-14, pp. 3009-3023, 2009. 


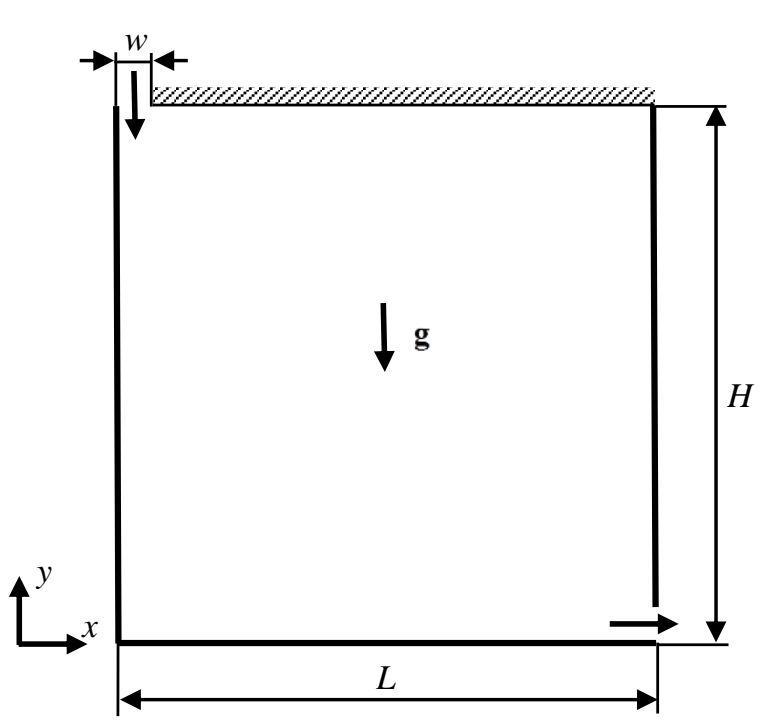

Figure 1. The geometry of the current model

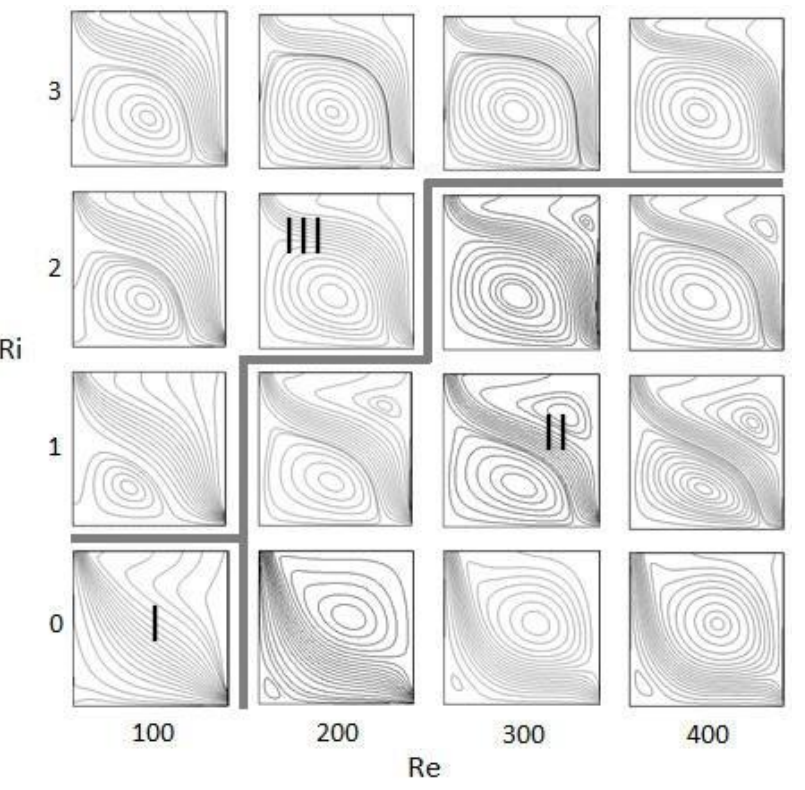

Figure 2. Flow modes for different $\mathrm{Re}$ and $\mathrm{Ri}$

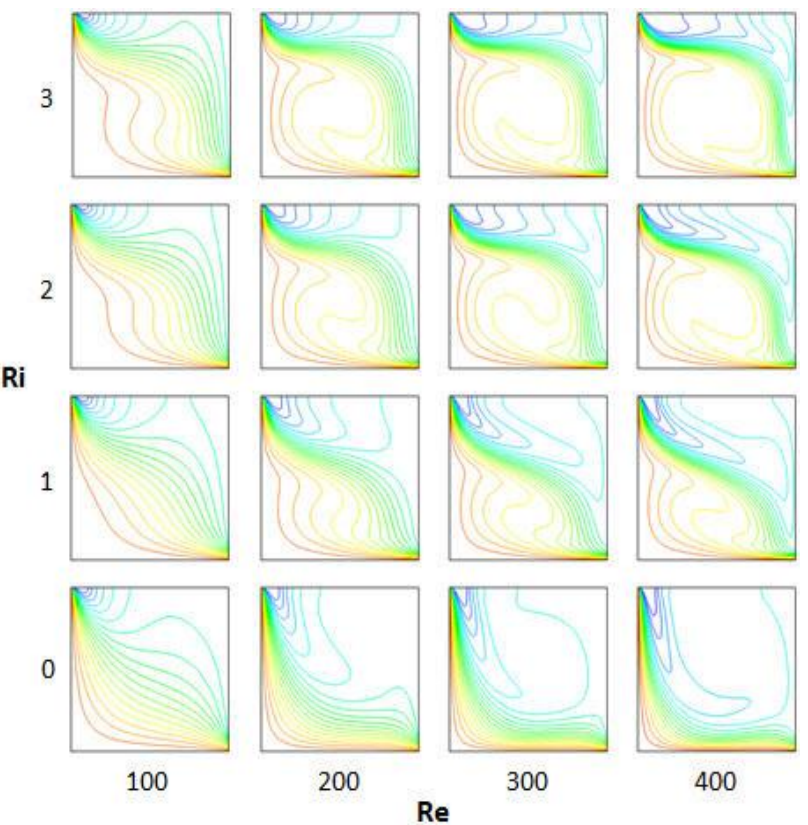

Figure 3. Isotherm contours for different $\mathrm{Re}$ and $\mathrm{Ri}$

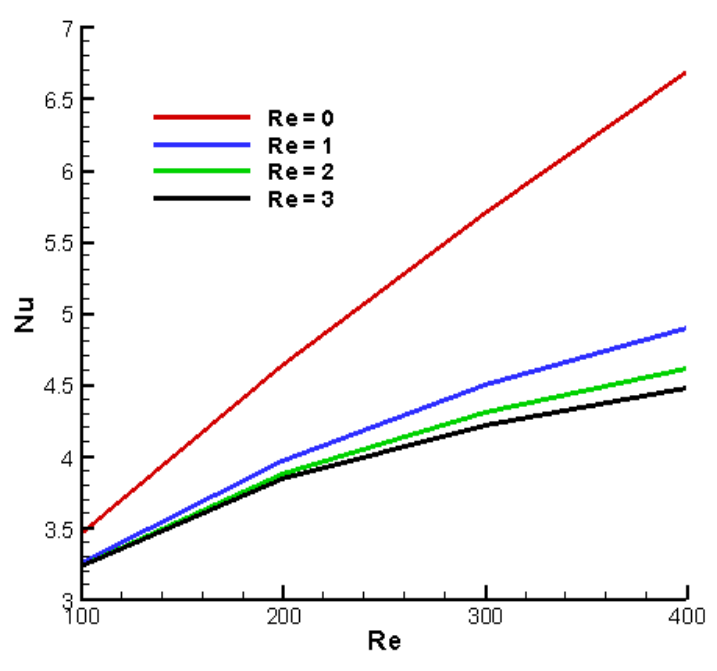

Figure 4. Nusselt number for different Re and Ri

TABLE 1.

OVERALL NUSSELT NUMBER FOR DIFFERENT GRID NUMBER, RE = 200, RI = 1

\begin{tabular}{|l|c|c|c|c|}
\hline & \multicolumn{5}{|c|}{ Grid size } \\
\cline { 2 - 5 } & $50 \times 50$ & $80 \times 80$ & $100 \times 100$ & $120 \times 120$ \\
\hline$\overline{N u}_{\text {ov }}$ & 6.528 & 4.639 & 3.963 & 3.962 \\
\hline
\end{tabular}

